\title{
IV. Oxygen Transport System Before and After Exposure to Chronic Hypoxia
}

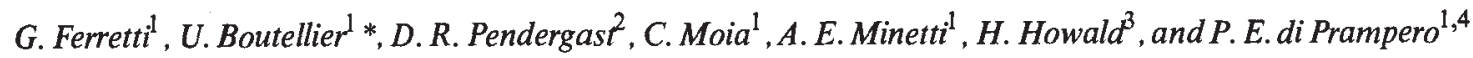 \\ ${ }^{1}$ Department of Physiology, University of Geneva Medical School, Geneva, Switzerland \\ ${ }^{2}$ Department of Physiology, State University of New York at Buffalo, Buffalo, NY, USA \\ ${ }^{3}$ Research Institute of the Swiss School of Physical Education and Sports, Magglingen, Switzerland \\ ${ }^{4}$ Institute of Biology, University of Udine, Udine, Italy
}

\begin{abstract}
G. Ferretti, U. Boutellier, D. R. Pendergast, C. Moia, A. E. Minetti, H. Howald, and P. E. di Prampero, Oxygen Transport System Before and After Exposure to Chronic Hypoxia. Int J Sports Med, Vol 11, Suppl 1, pp S15-\$20, 1990.

Maximal $\mathrm{VO}_{2}$ on the treadmill $\left(\mathrm{VO}_{2}\right.$ max $)$ and on the bicycle ergometer ( $\mathrm{VO}_{2}$ peak), maximal cardiac output ( $Q \max )$, by a $\mathrm{CO}_{2}$ rebreathing method, maximal heart rate (HRmax), blood hemoglobin concentration $(\mathrm{Hb})$, and hematocrit $(\mathrm{Hct})$ were measured on six subjects before (B) and 3 weeks after (A) prolonged exposure to chronic hypoxia. It was observed that after high-altitude exposure $\mathrm{VO}_{2} \max , \hat{V O}_{2}$ peak, and $\mathrm{Qmax}$ were lower $(P$ $<005)$ than before [A: $4.13 \pm 0.67 ; 3.28 \pm 0.41$ and $16.89 \pm 2.49(1 / \mathrm{min} \pm \mathrm{SD}) ; \mathrm{B}: 4.39 \pm 0.39 ; 3.53 \pm 0.34$ and $21.81 \pm 1.27$, respectively $]$, whereas $\mathrm{Hb}$ and Hct were larger (A: $162 \pm 8 \mathrm{~g} / 1$ and $0.46 \pm 0.02 ; \mathrm{B}: 142 \pm 7$ and $0.41 \pm 0.02)$ and HRmax was unchanged $(178 \pm 7$ vs $175 \pm 9 \mathrm{bts} / \mathrm{min})$. Thus, the calculated stroke volume of the heart and the $\mathrm{Hb}$ flow at $\mathrm{VO}_{2}$ peak were lower in $\mathrm{A}$ than in $B(95 \pm 15$ vs $124 \pm 7 \mathrm{ml}$ and $2,723 \pm 307$ vs $3,129 \pm 196$ $\mathrm{g} / \mathrm{min})(P<0.05$, respectively), whereas the arteriovenous $\mathrm{O}_{2}$ difference was greater in $\mathrm{A}$ than in $\mathrm{B}(195 \pm 16$ vs $162 \pm 19 \mathrm{ml} \mathrm{O}_{2} / 1 ; P<0.05$ ). At any given submaximal work load, $\mathrm{VO}_{2}$ and $\mathrm{HR}$ were the same in $\mathrm{B}$ and in $\mathrm{A}$, whereas $Q$ was lower in A by 2-3 1/min. However, because of the increased $\mathrm{Hb}$, leading to a higher arterial $\mathrm{O}_{2}$ content, at any work load the $\mathrm{O}_{2}$ flow remained unchanged.
\end{abstract}

\section{Key words}

maximum $\mathrm{O}_{2}$ consumption, cardiac output, limiting factors, hemoglobin, blood $\mathrm{O}_{2}$ concentration
Int. J.Sports Med. 11 (1990) S15-\$20

(c) Georg Thieme VerlagStuttgart - New York

\section{Introduction}

In chronic hypoxia both maximal oxygen uptake $\left(\mathrm{VO}_{2} \max \right)(5,21,22)$ and maximal cardiac output (Qmax) $(4,16,18,19)$ are known to be reduced. However, according to Cerretelli (5), "Qmax does not appear to be reduced enough to justify the decrease of $\mathrm{VO}_{2}$ max observed both breathing air and, particularly, oxygen." In fact, in chronic hypoxia the drop in $\mathrm{VO}_{2} \mathrm{max}$ is associated with an increase in blood hemoglobin concentration $(\mathrm{Hb})(5)$, a fact that tends to maintain the maximal hemoglobin flow, $\mathrm{M}_{\mathrm{Hb}}$, in spite of the reduced $\mathrm{Q}$ max. Also, upon return form altitude increased $\mathrm{Hb}$ is not accompanied by an equivalent rise in $\mathrm{VO}_{2} \max (4)$.

It is generally inferred from these data that the function of the $\mathrm{O}_{2}$ transport system is preserved by altitude acclimatization, and therefore it does not limit $\mathrm{VO}_{2} \max$ both at altitude (chronic hypoxia) and during the first days upon return to sea level (acclimatized subjects in normoxia, a condition here defined as acute normoxia). This conclusion is opposite to that believed to apply in normoxia for subjects not acclimatized to altitude (3). Surprisingly enough, this implies that the circulatory limits to $\mathrm{VO}_{2} \max$ described in normoxia shall disappear completely with chronic hypoxia. The relations between oxygen transport system and $\mathrm{VO}_{2}$ max after prolonged exposure to high altitude therefore deserve further studies.

The aim of the present paper is to describe the changes in $\mathrm{VO}_{2} \max$ and in the $\mathrm{O}_{2}$ transport system (cardiac output and hemoglobin flow) observed upon return from prolonged exposure to high altitude.

\section{Methods \\ Maximal Oxygen Uptake}

The maximal oxygen uptake $\left(\mathrm{VO}_{2} \max \right)$ was measured during treadmill running on a $+10 \%$ grade and during cycling. On the treadmill each subject ran first at 6 $\mathrm{km} / \mathrm{h}$ for $5 \mathrm{~min}$. Subsequently, he performed 3 to 5 runs of 3 min duration at increasing speed (from $7.5 \mathrm{~km} / \mathrm{h}$ to a maximum of $\left.13.5 \mathrm{~km} \cdot \mathrm{h}^{-1}\right)$. At the end of each work level blood samples were taken from the antecubital vein for lactate determination (Kontron, enzymatic method, 17), then the speed was increased by steps of $1.5 \mathrm{~km} / \mathrm{h}$. Expired air was collected

* Present address: Department of Physiology, University of Zurich, $\mathrm{CH}-8057$ Zurich, Switzerland 
Table 1 Physical characteristics and $\mathrm{VO}_{2}$ max before and after the expedition

\begin{tabular}{|c|c|c|c|c|c|c|c|c|}
\hline \multirow[t]{2}{*}{ Subj. } & \multirow[t]{2}{*}{$\begin{array}{l}\text { Age } \\
\text { (yrs) }\end{array}$} & \multirow[t]{2}{*}{$\begin{array}{l}\text { Height } \\
(\mathrm{cm})\end{array}$} & \multicolumn{2}{|c|}{$\begin{array}{l}\text { Weight } \\
(\mathrm{kg})\end{array}$} & \multicolumn{2}{|c|}{$\begin{array}{l}\text { VO } \max \\
(I \cdot \min -1)\end{array}$} & \multicolumn{2}{|c|}{$\begin{array}{l}\dot{\mathrm{VO}} 2 \max \\
(\mathrm{ml} \cdot \min -1 \cdot \mathrm{kg}-1\end{array}$} \\
\hline & & & Before & After & Before & After & Before & After \\
\hline GF & 50 & 176 & 71.4 & 66.5 & 4.49 & 4.28 & 62.9 & 64.4 \\
\hline LM & 37 & 179 & 76.0 & 73.0 & 4.53 & 4.46 & 59.6 & 61.1 \\
\hline MR & 44 & 167 & 66.6 & 63.2 & 3.62 & 2.86 & 54.3 & 45.3 \\
\hline RA & 38 & 177 & 69.7 & 64.9 & 4.38 & 4.09 & 62.8 & 63.0 \\
\hline $\mathrm{RM}$ & 30 & 174 & 79.7 & 74.7 & 4.65 & 4.22 & 58.3 & 56.5 \\
\hline WP & 44 & 183 & 75.3 & 77.0 & 4.67 & 4.84 & 62.0 & 62.9 \\
\hline $\bar{x}$ & 41 & 176 & 73.1 & 69.9 & 4.39 & 4.13 & 60.0 & 58.9 \\
\hline$\hat{S D}$ & 7 & 5 & 4.8 & 5.7 & 0.39 & 0.67 & 3.3 & 7.2 \\
\hline$\Delta \%$ & & & \multirow{2}{*}{\multicolumn{2}{|c|}{-4.4}} & \multirow{2}{*}{\multicolumn{2}{|c|}{-5.9}} & \multicolumn{2}{|c|}{-1.9} \\
\hline$t$ & & & & & & & \multirow{2}{*}{\multicolumn{2}{|c|}{-0.66}} \\
\hline $2 P$ & & & \multicolumn{2}{|c|}{-3.005} & \multicolumn{2}{|c|}{$\begin{array}{l}-2.05 \\
<0.10\end{array}$} & & \\
\hline
\end{tabular}

Table 2 Peak $\mathrm{VO}_{2}$ on the bicycle and the hemodynamic parameters before and after the expedition

\begin{tabular}{|c|c|c|c|c|c|c|c|c|c|c|}
\hline \multirow[t]{2}{*}{ Subj. } & \multicolumn{2}{|c|}{$\begin{array}{l}\text { VOapeak } \\
\left(1 \cdot \min ^{-1}\right)\end{array}$} & \multicolumn{2}{|c|}{$\begin{array}{l}\dot{Q} \max \\
\left(1 \cdot \min ^{-1}\right)\end{array}$} & \multicolumn{2}{|c|}{$\begin{array}{l}\text { HRmax } \\
\left(\min ^{-1}\right)\end{array}$} & \multicolumn{2}{|c|}{$\begin{array}{l}S V \\
(\mathrm{ml})\end{array}$} & \multicolumn{2}{|c|}{$\begin{array}{l}(\mathrm{Ca}-\mathrm{CV}) \mathrm{O}_{2} \\
\left(\mathrm{mlO}_{2} / \mathrm{l}\right)\end{array}$} \\
\hline & Before & After & Before & After & Before & After & Before & After & Before & After \\
\hline GF & 3.80 & 3.19 & 22.58 & 14.53 & 176 & 180 & 128 & 81 & 168 & 220 \\
\hline LM & 3.48 & 3.75 & 23.44 & 20.88 & 176 & 181 & 133 & 115 & 148 & 180 \\
\hline MR & 2.89 & 2.58 & 21.05 & 14.54 & 172 & 176 & 122 & 83 & 137 & 177 \\
\hline RA & 3.50 & 3.28 & 22.54 & 15.84 & 180 & 180 & 125 & 88 & 155 & 207 \\
\hline $\mathrm{RM}$ & 3.66 & 3.26 & 21.24 & 16.95 & 188 & 184 & 113 & 92 & 172 & 192 \\
\hline WF & 3.82 & 3.62 & 19.98 & 18.60 & 160 & 164 & 125 & 113 & 191 & 195 \\
\hline$\overline{\mathrm{x}}$ & 3.53 & 3.28 & 21.81 & 16.89 & 175 & 178 & 124 & 95 & 162 & 195 \\
\hline SD & 0.34 & 0.41 & 1.27 & 2.49 & 9 & 7 & 7 & 15 & 19 & 16 \\
\hline$\Delta(\%)$ & \multirow{2}{*}{\multicolumn{2}{|c|}{-7.1}} & \multicolumn{2}{|c|}{-22.6} & \multicolumn{2}{|c|}{+1.7} & \multicolumn{2}{|c|}{-23.4} & \multicolumn{2}{|c|}{+20.4} \\
\hline$t$ & & -2.05 & \multirow{2}{*}{\multicolumn{2}{|c|}{ - 4.62}} & \multicolumn{2}{|c|}{1.52} & \multicolumn{2}{|c|}{-5.12} & \multicolumn{2}{|c|}{4.32} \\
\hline $2 P$ & \multicolumn{2}{|c|}{$<0.10$} & $<0.01$ & & \multicolumn{2}{|c|}{ NS } & \multicolumn{2}{|c|}{$<0.01$} & \multicolumn{2}{|c|}{$<0.01$} \\
\hline
\end{tabular}

in three Douglas bags during the last $1.5 \mathrm{~min}$ of each work and subsequently analyzed for gas composition (A-52 Applied Electrochemistry $\mathrm{O}_{2}$ meter and LB-2 Beckman $\mathrm{CO}_{2}$ meter) and volume (Singer dry gas meter). The average value of the three $\mathrm{VO}_{2}$ measurements was taken as the $\mathrm{VO}_{2}$ of the test. Heart rate was measured continuously by ECG. The following criteria were used for establishing that $\mathrm{VO}_{2}$ max had indeed been attained: (1) an increase in $\mathrm{VO}_{2}$ of less than $2 \%$ between two successive runs; (2) the attainment of maximal heart rate $\left(\Delta \mathrm{HR}<5 \mathrm{~min}^{-1}\right)$; (3) blood lactate exceeding $7 \mathrm{mM}$ at the end of the highest work load; (4) subject's exhaustion.

On the bicycle ergometer a maximal work load corresponding to $90 \%$ of $\mathrm{VO}_{2} \max$ on the treadmill (3) was chosen. Four exercise levels were then selected, corresponding to $25 \%, 50 \%, 75 \%$, and $100 \%$ of the calculated maximal work load. At each work load steady-state $\mathrm{O}_{2}$ consumption was measured by standard open circuit method, as described above. The highest measured $\mathrm{VO}_{2}$ value was retained as the maximal $\mathrm{O}_{2}$ uptake on the bicycle ergometer ( $\mathrm{VO}_{2}$ peak).

\section{Cardiac Output}

Steady-state cardiac output during cycloergometric exercise (Q) was determined by means of a $\mathrm{CO}_{2}$ rebreathing method (10) in the course of the same protocol as for the determination of $\mathrm{VO}_{2}$ peak. A mass spectrometer (Centronic $200 \mathrm{MGA}$ ) was used for gas analysis. The $\mathrm{CO}_{2}$ rebreath- ing traces were followed on paper (Grass 7D), stored on discs, and subsequently analyzed by a computer (IBM XT 286). The $Q$ calculations were performed in a blind manner by a technician not involved in this study. At each work load three determinations of $Q$ were performed, and the mean value was retained and utilized in subsequent data analysis. The highest measured $Q$ value was taken as the maximal cardiac output (Qmax). During the same protocol heart rate (HR) was measured by cardiotachography. The stroke volume of the heart (SV) was calculated as the ratio of $Q$ to $H R$. The overall arteriovenous difference for oxygen, $\left(\mathrm{Ca}-\mathrm{Cv}-\mathrm{O}_{2}\right.$, was calculated as the ratio of $\mathrm{VO}_{2}$ to $Q$.

\section{Hematologic Data}

Blood hematocrit (Hct) and hemoglobin concentration $(\mathrm{Hb})$ were determined by standard laboratory techniques. The hemoglobin flow (M.Hb) was then calculated as the product of $\mathrm{Hb}$ times $\mathbf{Q}$.

\section{Subjects}

Six subjects, all experienced climbers who participated in the 1986 Swiss Expedition to Mount Everest, volunteered for the present study and signed an informed consent. Their physical characteristics appear in Table 1. They were tested in Magglingen ( $\left.\mathrm{VO}_{2} \max \right)$ and in Geneva $(\mathrm{Q})$ before departure and 3 weeks after return to sea level. Details 


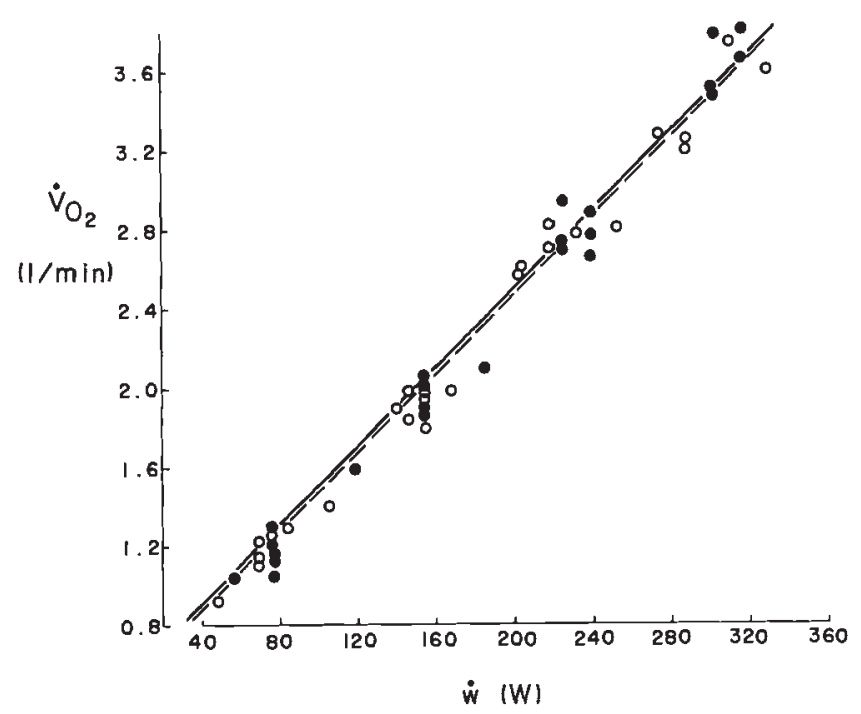

Fig. $1 \mathrm{O}_{2}$ consumption $\left(\mathrm{V}_{2}\right)$ as a function of the work rate $(\dot{w})$ in $\mathrm{B}$ (O) and in $\mathrm{A}(\mathrm{O})$. In $\mathrm{B}, \mathrm{VO}_{2}=0.44+0.010 \dot{w}, r=0.993, n=24 . \operatorname{In} \mathrm{A}$, $\dot{V}_{2}=0.32+0.011 \dot{w}_{1} r=0.993, n=24$. The two equations are not statistically different $(2 P>0.10$ for both the slope and the intercept).

of expedition and altitude exposure timing appear in paper I (7).

\section{Results \\ Body Weightand VO 2 max}

Individual data of body weight (BW) and $\mathrm{VO}_{2}$ max before (B) and after (A) the expedition appear in Table 1. BW was $73.1 \pm 4.8 \mathrm{~kg}$ in B and $69.9 \pm 57 \mathrm{~kg}$ in A $(2 P$ $<0.10$ ). $\mathrm{VO}_{2} \max$ was $4.39 \pm .0391 \pm \mathrm{min}^{-1}$ in $\mathrm{B}$ and $4.13 \pm 0.671 \cdot \mathrm{min}^{-1}$ in $\mathrm{A}$. In $\mathrm{A}$ the decrease in $\mathrm{VO}_{2} \max$ was slightly greater $\left(\triangle \mathrm{VO}_{2} \max =-5.9 \% ; 2 P<0.10\right)$ than the drop in $\mathrm{BW}$. Once standardized per $\mathrm{Kg}$ of $\mathrm{BW}, \mathrm{VO}_{2} \max$ decreased from $60 \pm 3.3 \mathrm{ml} \cdot \mathrm{min}^{-1}$ in $\mathrm{B}$ to $59 \pm 7.2 \mathrm{ml} \cdot \mathrm{Kg}^{-1}$ $\cdot \min ^{1}$ in $\mathrm{A}(2 P>0.10)$. At the highest speed Lab was $7.68 \pm 3.03 \mathrm{mM}$ and $8.29 \pm 1.43 \mathrm{mM}$ in B and A, respectively, the difference being not significant $(2 P>0.10)$.

On the bicycle ergometer the maximum measured $\mathrm{VO}_{2}$ ( $\left(\mathrm{VO}_{2}\right.$ peak) was $3.53 \pm 0.341 \cdot \mathrm{min}^{1}$ in $\mathrm{B}$ and $3.28 \pm 0.411 \cdot \mathrm{min}^{-1}$ in A (Table 2), i. e., $80.4 \%$ and $79.4 \%$ of $\mathrm{VO}_{2 m a x}$, respectively. The corresponding work loads were $295 \pm 29$ and $281 \pm 43 \mathrm{~W}$ in B and A, respectively ( $2 P$ $>0.10$ ). The decrease in $\mathrm{VO}_{2}$ peak in A was slightly greater than that in $\mathrm{VO}_{2} \max \left(\triangle \mathrm{VO}_{2}\right.$ peak $\left.=-7.1 \% ; 2 P<0.10\right)$. At any given submaximal work load, equal values for $\mathrm{VO}_{2}$ were found in B and in A (Fig. 1), the net mechanical efficiency being $0.267 \pm 0.022$ and $0.254 \pm 0.019$, respectively.

\section{Hemodynamic Parameters}

Individual data of heart rate on the bicycle ergometer(HR) in B and in A are plotted in Fig. 2 as a function of $\mathrm{VO}_{2}$. The resulting linear relationships are not statistically different $(2 P>0.10)$. Maximal HR was $175 \pm 9 \mathrm{~min}^{-1}$ in B and $178 \pm 7$ in $\mathrm{A}(2 P>0.10)$.

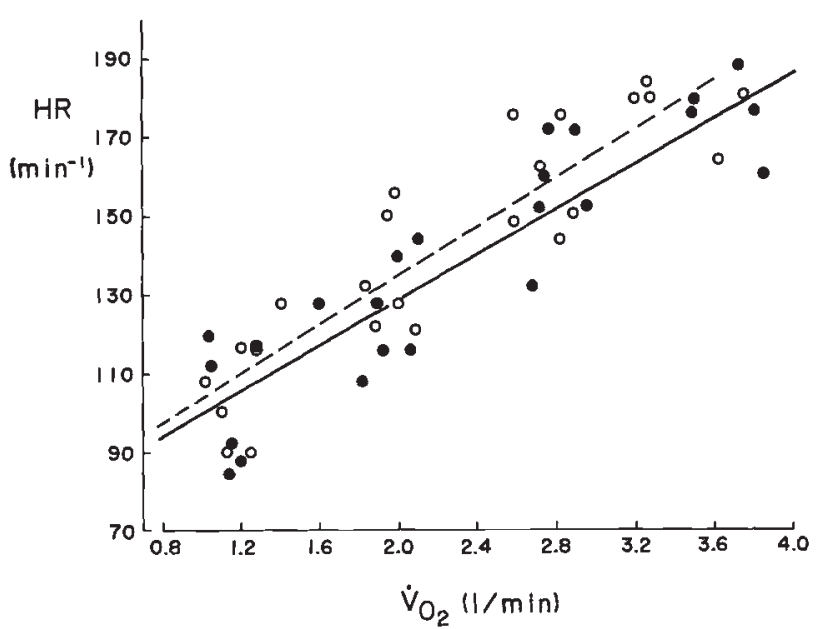

Fig. 2 Heart rate (HR) as a function of $\mathrm{VO}_{2}$ in $B(O)$ and in $A(O)$. In $\mathrm{B}, \mathrm{HR}=71.44+28.45 \mathrm{VO}_{2}, r=0.905, n=24$. In $\mathrm{A}$,

$\mathrm{HR}=72.66+31.07 \mathrm{VO}_{2}, r=0.894, n=24$. The two equations are not statistically different.

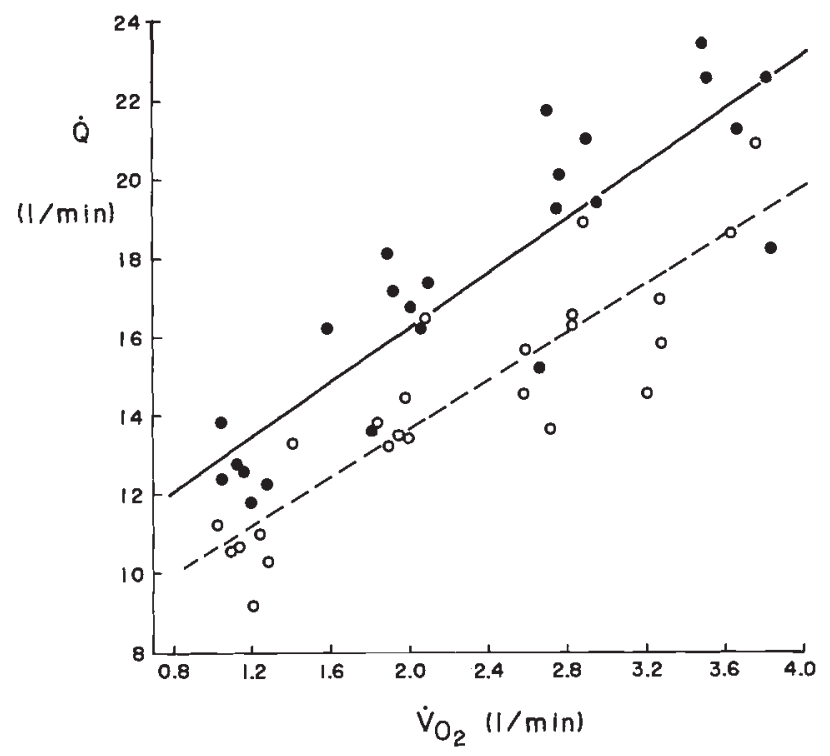

Fig. 3 Cardiac output (Q) as a function of $\mathrm{VO}_{2}$ in $\mathrm{B}(\mathbf{O})$ and in $\mathrm{A}$ (O). $\ln \mathrm{B}, \mathrm{Q}=9.264+3.50 \mathrm{VO}_{2}, r=0.881, n=24 . \ln \mathrm{A}$,

$Q=7.495+3.05 \mathrm{VO}_{2}, r=0.886, n=24$. The two lines appear to be parallel. ( $2 P>0.10$ for the slope, and $2 P<0.10$ for the intercept).

In both $\mathrm{B}$ and $\mathrm{A}$ the relationship between cardiac output $(\mathrm{Q})$ and $\mathrm{V}_{2}$ can be approximated by a straight line (Fig. 3). The two lines have almost indentical slope but different intercepts $(2 P<0.10)$ so that at any given submaximal work load, $Q$ is lower in A by $\sim 2-31 \cdot \mathrm{min}^{-1}$. Maximal $Q$ (Qmax) was $21.81 \pm 1.271 \cdot \mathrm{min}^{-1}$ and $16.89 \pm 2.491 \cdot \mathrm{min}^{-1}$ in $B$ and $A$, respectively (Table 2$)$, the difference $(\Delta Q \max =$ $-22.6 \%)$ being highly significant $(2 P<0.01)$.

Since HR is the same in B and in A, the drop in $Q$ must be due to an equivalent reduction in stroke volume (SV). Maximal calculated SV was $124 \pm 7 \mathrm{ml}$ in B and $95 \pm 15$ 
Table 3 Hematologic variables before and after the expedition

\begin{tabular}{|c|c|c|c|c|c|c|}
\hline \multirow[t]{2}{*}{ Subj. } & \multicolumn{2}{|c|}{$\begin{array}{l}\mathrm{Hb} \\
\left(\mathrm{g} \cdot \mathrm{I}^{-1}\right)\end{array}$} & \multicolumn{2}{|c|}{$\begin{array}{l}\mathrm{HCt} \\
(\%)\end{array}$} & \multicolumn{2}{|c|}{$\begin{array}{l}\mathrm{M}_{\mathrm{Hb}} \\
\left(\mathrm{g} \cdot \min ^{-1}\right)\end{array}$} \\
\hline & Before & After & Before & After & Before & After \\
\hline GF & 140 & 168 & 41 & 48 & 3161 & 2441 \\
\hline LM & 145 & 157 & 41 & 43 & 3399 & 3278 \\
\hline MR & 130 & 168 & 40 & 48 & 2884 & 2443 \\
\hline RA & 146 & 170 & 40 & 46 & 3291 & 2693 \\
\hline RM & 145 & 159 & 44 & 45 & 3080 & 2695 \\
\hline WF & 148 & 150 & 42 & 44 & 2957 & 2790 \\
\hline $\bar{x}$ & 142 & 162 & 41 & 46 & 3129 & 2723 \\
\hline SD & 7 & 8 & 2 & 2 & 196 & 307 \\
\hline$\Delta(\%)$ & \multicolumn{2}{|c|}{+14.1} & \multirow{2}{*}{\multicolumn{2}{|c|}{$\begin{array}{l}+12.2 \\
352\end{array}$}} & \multicolumn{2}{|c|}{-13.0} \\
\hline$t$ & \multicolumn{2}{|c|}{3.75} & & & \multirow{2}{*}{\multicolumn{2}{|c|}{$<0.01$}} \\
\hline $2 P$ & \multicolumn{2}{|c|}{$<0.05$} & \multicolumn{2}{|c|}{$<0,05$} & & \\
\hline
\end{tabular}

$\mathrm{ml}$ in $\mathrm{A}$ (Table 2$)$, the value in $\mathrm{A}$ being $23.4 \%$ less than in $\mathrm{B}(2 P$ $<0.01)$.

Maximal arteriovenous differences for $\mathrm{O}_{2}$, ( $\mathrm{Ca}-\mathrm{Cv}-\mathrm{O}_{2}$, were about $20 \%$ higher in $\mathrm{A}$ than in $\mathrm{B}$, amounting to $162 \pm 19 \mathrm{ml} \mathrm{O}_{2} / 1$ and to $195 \pm 16 \mathrm{ml} \mathrm{O}_{2} / 1$, respectively $(2 P<0.01)$. When $(\mathrm{Ca}-\mathrm{C} \overline{\mathrm{v}}) \mathrm{O}_{2}$ was expressed relative to the maximal blood $\mathrm{O}_{2}$-carrying capacity, the calculated values were much closer $(0.84 \pm 0.087$ and $0.90 \pm 0.072$ in B and $A$, respectively) but still significantly different $(2 P<0.10)$.

\section{Hematologic Data}

Blood hemoglobin concentration $(\mathrm{Hb})$ and hematocrit (Hct) are given in Table 3. Hb was $142 \pm 7 \mathrm{~g} \cdot \mathrm{I}^{-1}$ in B and $162 \pm 8 \mathrm{~g} \cdot \mathrm{l}^{-1}$ in A. Similarly, Hct increased from $41 \pm 2 \%$ in B to $46 \pm 2 \%$ in A. Thus, Hb and Hct were $14.1 \%$ and $12.2 \%$ greater in $A$ than in $B$, the difference being significant in both cases $(2 P<0.10)$.

The relationship between the hemoglobin flow, $\mathrm{M} \cdot \mathrm{Hb}$ and $\mathrm{VO}_{2}$ is described in Fig. 4. For submaximal $\mathrm{VO}_{2}$ values, no difference between $B$ and $A$ was observed, the two lines being statistically equal $(2 P>0.10)$.

However, since the reduction in Qmax was greater than the increase in $\mathrm{Hb}$, the maximal hemoglobin flow, $\mathrm{M}_{\mathrm{Hb}}, \max =\max \pm \mathrm{Hb}$, appeared to be $13 \%$ lower in $\mathrm{A}$ $\left(2,723 \pm 307 \mathrm{~g} \cdot \mathrm{min}^{-1}\right)$ than in $\mathrm{B}\left(3,129 \pm 196 \mathrm{~g} \cdot \mathrm{min}^{-1}\right)(2 P$ $<0.01$ ).

\section{Discussion \\ Maximal $\mathrm{O}_{2}$ Consumption and Maximal Cardiac Output}

The maximal $\mathrm{O}_{2}$ consumption $\left(\mathrm{VO}_{2} \max \right)$ in $\mathrm{B}$ appeared to be greater than that of sedentary untrained subjects of the same age (2) and equal to that of world-class climbers (15). The observed values of $\mathrm{VO}_{2}$ max and of maximal cardiac output (Table 2) permit a classification of the present subjects as nonathletic well-trained individuals (6). These data therefore confirm the conclusions drawn by Oelz et al. (15) that a very high $\dot{V O}_{2}$ max is not the most critical physiological parameter required for successful Himalayan climbers. Actually, the best climbers in the world and the present subjects,

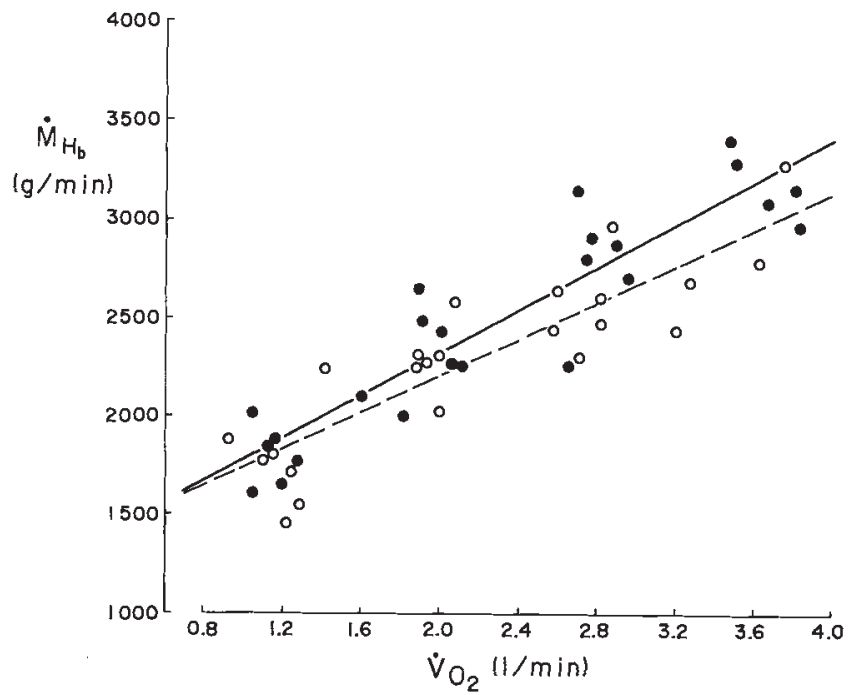

Fig. 4 Hemoglobin flow (M $\left.\dot{M}_{H b}\right)$ as a function of $\mathrm{VO}_{2}$ in $\mathrm{B}(-)$ and in $\mathrm{A}$ (O). $\ln \mathrm{B}, \dot{\mathrm{M}}_{\mathrm{Hb}}=1239+540 \dot{\mathrm{VO}}_{2}, r=0.915, n=24$. $\ln \mathrm{A}$, $\dot{\mathrm{M}}_{\mathrm{Hb}}=1280+463 \mathrm{~V}_{2}, r=0.881, n=24$. The two equations are not statistically different.

who incidentally failed to reach the summit of Mt. Everest, have the same $\mathrm{VO}_{2}$ max.

Upon return from the expedition, absolute $\mathrm{VO}_{2}$ max was slightly but significantly lower than before departure, whereas specific $\mathrm{VO}_{2} \max$ (in $\mathrm{ml} \cdot \mathrm{min}^{-1} \cdot \mathrm{kg}^{-1}$ ) was practically unchanged. In conditions similar to those of the present study, Cerretelli (4) found slightly higher values of $\mathrm{VO}_{2}$ max after acclimatization. He observed, however, that $\mathrm{VO}_{2}$ max was less than that expected, ceteris paribus, from the observed increase in blood hemoglobin due to acclimatization. His data are confirmed also by the present study, showing that $\mathrm{VO}_{2}$ max did not incrase in $\mathrm{A}$ in spite of a $14 \%$ increase in blood hemoglobin. Such an increase, in fact, was offset by a concomitant $23 \%$ reduction in maximal cardiac output, resulting in a reduced maximal hemoglobin flow.

On the bicycle ergometer the peak observed $\dot{\mathrm{VO}}_{2}$ values were $20 \%$ lower than treadmill $\mathrm{VO}_{2}$ max, both in $\mathrm{B}$ and in $\mathrm{A}$. This might be due to either the exercise mode or to the characteristics of the ergometer. In fact, (1) since during cycling the working muscles are contracted for a longer time than in running, lactate starts accumulating in muscles at lower work loads; and (2) during cycling a smaller muscle mass is utilized than during running.

Qmax in A appears to be markedly reduced with respect to $\mathrm{B}$ (Table 2 ). This reduction is much greater than that of $\mathrm{VO}_{2}$ max, suggesting that an increased $(\mathrm{Ca}-\mathrm{C} \bar{v}) \mathrm{O}_{2}$ partially compensates for the reduced Qmax. The rather low Qmax values observed in A may raise some doubts. However, the measurements of Qmax in the present study have been obtained by means of a $\mathrm{CO}_{2}$ rebreathing technique reported to be very reliable with respect to other methods $(10)$. In addition,

1. the $Q$ vs $V_{2}$ relationship in $B$ is not significantly different from previous values reported in the literature (6)

2. Qmax is pretty close to the average values reported in the literature for trained nonathletic subjects (9) 
Table $4 \mathrm{O}_{2}$ transport before $(B)$ and after $(A)$ the expedition

\begin{tabular}{|c|c|c|c|c|c|c|}
\hline \multicolumn{2}{|c|}{$\begin{array}{l}\mathrm{VO}_{2} \\
\left(1 \cdot \min ^{-1}\right)\end{array}$} & \multicolumn{2}{|c|}{$\begin{array}{l}\mathrm{QO}_{2} \\
\left(1 \cdot \min ^{-1}\right)\end{array}$} & \multicolumn{2}{|c|}{$\begin{array}{l}\mathrm{VO}_{2} / \mathrm{Q}_{2} \\
(\mathrm{Ca}-\mathrm{CV}) \mathrm{O}_{2}\end{array}$} & \multirow[t]{2}{*}{$\begin{array}{l}W \\
(\%)\end{array}$} \\
\hline B & A & B & A & B & A & \\
\hline 1.14 & 1.15 & 2.40 & 2.27 & 0.48 & 0.51 & 25 \\
\hline 1.88 & 1.86 & 3.11 & 3.06 & 0.60 & 0.61 & 50 \\
\hline 2.65 & 2.63 & 3.59 & 3.41 & 0.74 & 0.77 & 75 \\
\hline 3.53 & 3.28 & 4.19 & 3.65 & 0.84 & 0.90 & 100 \\
\hline
\end{tabular}

$\mathrm{O}_{2}$ uptake $\left(\mathrm{VO}_{2}\right.$ flow $\left(\mathrm{QO}_{2}\right)$ and extraction $\left(\mathrm{VO}_{2} / \mathrm{Q} \mathrm{O}_{2}\right)$ at given submaximal loads $\left(\mathrm{W}, \mathrm{QO}_{2}\right.$ is calculated from $\mathrm{Hb}$, assuming that $1 \mathrm{~g}$ of $\mathrm{Hb}$ links $1.34 \mathrm{mlO}_{2}$

3. the calculated $(\mathrm{Ca}-\mathrm{Cv}) \mathrm{O}_{2}$ difference for $\mathrm{A}$ is within the expected physiological range.

Chronic exposure to hypoxia increased $\mathrm{Hb}$ and Hct (see Table 3), consistent with the data reported by others (3-5). However, the remarkable decrease in Qmax ($22 \%$, Table 2) more than compensated for the increased $\mathrm{Hb}$ and $\mathrm{Hct}$ so that $\mathrm{O}_{2}$ transport by blood convection $\left(\mathrm{QO}_{2}\right)$ was smaller in A than in B $(-13 \%)$. This clearly explains why $\mathrm{VO}_{2}$ max did not increase in $\mathrm{A}$. On the contrary, after the finding that chronic hypoxia deteriorates muscle function, as shown by the reported decrease in mitochondrial density and in the activity of oxidative enzymes $(12,13)$, one should expect a greater decrease in both $\mathrm{VO}_{2}$ max and $\mathrm{VO}_{2}$ peak than in $\mathrm{QO}_{2}$. This was not the case in the present study since $\mathrm{VO}_{2} \max$ and $\mathrm{VO}_{2}$ peak decreased by $6 \%-7 \%$ only. Therefore, the deteriorated muscle function had to be compensated for by some other factor than facilitated $\mathrm{O}_{2}$ flow. Such a factor could be the increased capillary density consequent to the reduced muscle fiber size (12), which enhances $\mathrm{O}_{2}$ diffusion from the capillaries to the mitochondria.

\section{Regulation of $\mathrm{O}_{2}$ Transport at Submaximal Exercise}

At any submaximal work load, the muscles take up as much oxygen as they need, either in normoxia, or in acute hypoxia, chronic hypoxia, and acute normoxia (present subjects in $\mathrm{A}$ ), irrespective of $\mathrm{CaO}_{2}$. By contrast, at any given work load, $Q$ in $A$ is $2-31 / \mathrm{min}$ less than in $B$ so that the relationship between $Q$ and $\mathrm{VO}_{2}$ in acute normoxia is shifted downward (Fig. 3). On the other hand, in acute hypoxia (20) the Q vs VO2 relationship is shifted upward, whereas after acclimatization to chronic hypoxia, the $Q$ vs $\mathrm{VO}_{2}$ relationship is the same as in normoxic conditions $(4,16,18,19)$.

The series of events determining the reported shifts of the $\mathrm{Q} / \mathrm{vs} \mathrm{VO}_{2}$ relationship can be described as follows. When $\mathrm{PIO}_{2}$ is suddenly decreased, e. g., from 159 to 97 Torr (20), $\mathrm{SaO}_{2}$ at a $100 \mathrm{~W}$ work level decreases from 0.96 to 0.71. Therefore, $\mathrm{QO}_{2}$ decreases, and $\mathrm{O}_{2}$ extraction increases, thus leading to a lower $\mathrm{P}^{-} \mathrm{O}_{2}$. Prehypoxic values of $\mathrm{QO}_{2}, \mathrm{O}_{2}$ extraction, and $\mathrm{P}_{\bar{v}}^{-} \mathrm{O}_{2}$ are then reestablished by a corresponding increase in $\mathrm{Q}$, which compensates for the decreased $\mathrm{SaO}_{2}$. These series of adjustments result in a $Q$ vs $\mathrm{VO}_{2}$ relationship shifted upward. If the exposure to hypoxia is prolonged, the synthesis of erythropoietin is stimulated $(1,8)$, which in turn increases $\mathrm{Hb}$. This adaptation tends to increase $\mathrm{QO}_{2}$, to reduce $\mathrm{O}_{2}$ extraction, and to increase $\mathrm{P}^{-} \mathrm{O}_{2}$. The readjustment of these parameters leads to a corresponding reduction in $Q$ so

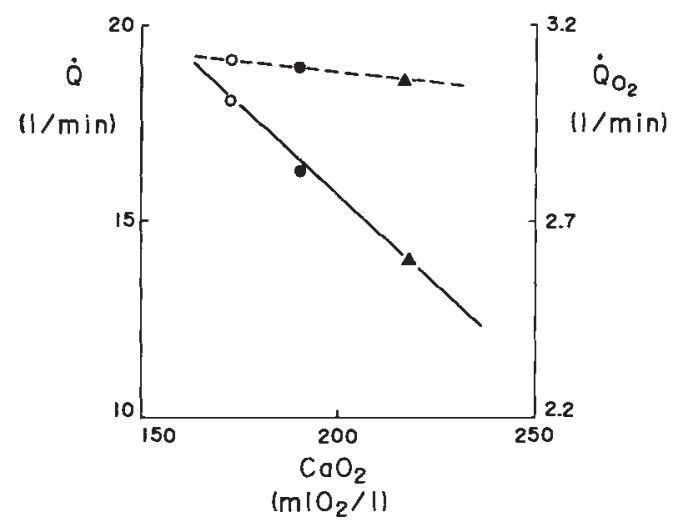

Fig. 5 Cardiac output ( $Q$, left ordinate, continuous line) and $\mathrm{O}_{2}$ flow $\left(\mathrm{Q} \mathrm{O}_{2}\right.$, right ordinate, dashed line) as a function of $\mathrm{CaO}_{2}$ at a work rate of $140 \mathrm{~W}$ ( $50 \%$ of present subjects' $\mathrm{VO}_{2}$ peak). $\mathrm{O}$, acute hypoxia, from Stenberget al. (22) . and $\mathbf{\Delta}$ are the present data in normoxia and acute normoxia, respectively.

that in chronic hypoxia the relationship between $\mathrm{Q}$ and $\mathrm{VO}_{2}$ is equal to that observed in normoxia $(16,18,19)$. A sudden return to sea level, as in the present study in $\mathrm{A}$, moves $\mathrm{SaO}_{2}$ back to 1 . However, since $\mathrm{Hb}$ is still elevated, this would lead to an increase in $\mathrm{QO}_{2}$ and $\mathrm{PvO}_{2}$ and a decrease in $\mathrm{O}_{2}$ extraction. These changes are modulated by a reduction in $Q$. As a result, the $Q$ vs $\dot{V O}_{2}$ relationship in acute normoxia is shifted downward with respect to normoxia (Fig. 3), whereas $\mathrm{QO}_{2}$ and $\mathrm{O}_{2}$ extraction are practically unchanged (Table 4). Thus, on the one hand, the $\mathrm{Q}$ vs $\mathrm{VO}_{2}$ relationship for a given $\mathrm{PIO}_{2}$ appears to be affected by changes in the $\mathrm{Hb}$ concentration (normal $\mathrm{PO}_{2}$, normoxia vs acute normoxia; low $\mathrm{PO}_{2}$, acute hypoxia vs chronic hypoxia). On the other hand, for a given $\mathrm{Hb}$ concentration, the $\mathrm{Q}$ vs $\mathrm{VO}_{2}$ relationship is affected by changes in $\mathrm{PIO}_{2}$ (normal $\mathrm{Hb}$, normoxia vs acute hypoxia; high $\mathrm{Hb}$, chronic hypoxia vs acute normoxia).

In conclusion, at any given work load, Qseems to be regulated in such a way as to keep $\mathrm{QO}_{2}$ constant, independent of $\mathrm{CaO}_{2}$. This is shown in Fig. 5, where $\mathrm{Q}$ and $\mathrm{QO}_{2}$ are plotted as a function of $\mathrm{CaO}_{2}$, for a work load of $140 \mathrm{~W}$, corresponding to $50 \%$ of the present subjects' $\mathrm{VO}_{2} \max$. Q is negatively related to $\mathrm{CaO}_{2}$ : it increases by $93 \mathrm{ml} / \mathrm{min}$ per $1 \mathrm{ml} / 1$ decrease in $\mathrm{CaO}_{2}$. On the other hand, the $\mathrm{QO}_{2}$ vs $\mathrm{CaO}_{2}$ relationship is practically parallel to the abscissa.

On these bases, it is tempting to postulate that, for any given work load, the absolute $Q$ level is set not only by the work intensity, but also by $\mathrm{CaO}_{2}$. If it is so, then

1. the position of the $Q$ vs $\mathrm{CaO}_{2}$ function should be set by (e. g.) $\mathrm{PvO}_{2}$-sensitive receptors (11) and/or other peripheral and/or central mechanisms assumed to regulate $Q$ as a function of the work intensity

2. the slope of the $Q$ vs $\mathrm{CaO}_{2}$ line of Fig. $5(93 \mathrm{ml} / \mathrm{min}$ per $\mathrm{ml} / \mathrm{l}$ ) indicates the gain of the system, which finely tunes $Q$ on the basis of $\mathrm{CaO}_{2}$

3. the carotid body can be viewed as the sensor organ responsible for this fine tuning.

However, what the carotid body is sensitive to (reduced $\mathrm{PaO}_{2}, \mathrm{CaO}_{2}$, or carotid body $\mathrm{QO}_{2}$, see 11,14 ) is un- 
clear: sensitivity to $\mathrm{PaO}_{2}$ alone is to be ruled out as it would not be compatible with the present data. The stimulation of the receptor, on the other hand, may lead to changes in Q, mediated by combined changes in the sympathetic and in the vagal activity. Indeed, in the present "acute normoxia" condition (A), HR is essentially the same as in normoxia (B), whereas the SV is lower. This is compatible with a normal sympathetic tone and a reduced vagal tone.

\section{Conclusions}

The present experiments have shown that, upon return from a 10 -week altitude exposure, $\mathrm{VO}_{2} \max$ is slightly decreased $(-5.9 \%)$, whereas Qmax is decreased by a greater extent $(-22.6 \%)$, thus, more than compensating for the increase in $\mathrm{Hb}(+14.1 \%)$ and in $\mathrm{Hct}(+12.2 \%)$. The drop of Qmax follows a reduction in SV rather than in HR, and it leads to greater $(\mathrm{Ca}-\overline{\mathrm{Cv}}) \mathrm{O}_{2}$ differences. At submaximal exercise, $\mathrm{VO}_{2}$ is equal to that in the control condition before departure, whereas $Q$ is $2-31 \cdot \mathrm{min}^{-1}$ lower. The decrease in $Q$ compensates for the higher $\mathrm{O}_{2}$ concentration (or lower, $\mathrm{Pv}-\mathrm{O}_{2}$ ) associated with increased $\mathrm{Hb}$. This allows $\mathrm{O}_{2}$ transport at any given submaximal work load to be practically constant.

\section{Acknowledgement}

A. E. Minetti was A NATO-CNR fellow, on leave from Centro Studi di Fisiologia del Lavoro Muscolare, CNR, Milano, Italy.

\section{References}

1 Abbrecht P. H., Littel J. K.: Plasma erythropoietin in men and mice during acclimatization to different altitudes. $J$ Appl Physiol $32: 54-58,1972$.

2 Åstrand P. O., Christensen E. H.: Aerobic work capacity, in Dickens F., Neil E., Widdas W. F. (eds): Oxygen in the Animal Organism. New York, Pergamon Press, 1964, pp 295-303.

3 Astrand P. O., Rodahl K.: Textbook of Work Physiology. New York, Mc Graw Hill, 1977.

4 Cerretelli P.: Limiting factors to oxygen transport on Mount Everest. J Appl Physiol 40:658-667, 1976.

5 Cerretelli P.: Gas exchange at altitude, in West J. B. (ed): Pulmonary Gas Exchange. Vol II : Organism and Environment. New York, Academic Press, 1980, pp 97-147.

6 Cerretelli P., di Prampero P. E.: Gas exchange in exercise, in Fahri L. E., Tenney S. M. (eds): Handbook of Physiology. The Respiratory System IV. Bethesda, MD, Am. Physiol. Soc., 1987, pp 297-339.

7 Cerretelli P., di Prampero P. E.: A multidisciplinary approach to the study of the effects of altitude on muscle structure and function. Int I Sports Med(this supplement).
8 Eckardt K. U., Boutellier U., Kurtz A., Schopen M., Koller E. A., Bauer C.: Rate of erythropoietin formation in humans in response to acute hypobaric hypoxia. J Appl Physiol 66: 1785-1788, 1989.

9 Ekblom B., Àstrand P. O., Saltin B., Stenberg J., Wallstrom B.: Effect of training on circulatory response to exercise. J Appl Physiol $24: 518-528,1968$

10 Farhi L. E., Nesarajah M. S., Olszowka A. J., Metildi L. A., Ellis A. K.: Cardiac output determination by a simple one step rebreathing technique. Respir Physiol 28 : 141-159, 1976.

11 Fitzgerald R. S., Lahiri S.: Reflex responses to chemoreceptor stimulation, in Cherniack N. S., Widdicombe J. G. (eds): Handbook of Physiology. The Respiratory System II. Bethesda, MD, Am. Physiol. Soc., 1986, pp 313-362.

12 Hoppeler H., Kleinert K., Schlegel C., Claassen H., Howald H., Cerretelli P.: Morphological adaptations of human skeletal muscle to chronic hypoxia. Int J Sports Med (this supplement).

13 Howald H., Pette D., Simoneau J.-A., Uber A., Hoppeler H., Cerretelli P.: Effects of chronic hypoxia on muscle enzymes. Int $J$ Sports Med (this supplement).

14 Lahiri S.: Role of arterial $\mathrm{O}_{2}$ flow in peripheral chemoreceptor excitation. Fed. Proc 39: 2648-2652, 1980.

15 Oelz O., Howald H., di Prampero P. E., Hoppeler H., Claassen H., Jenni R., Bühlmann A., Ferretti G., Brückner J. C., Veicsteinas A., Gussoni M., Cerretelli P.: Physiological profile of world-class high-altitude climbers. J Appl Physiol 60: 1734-1742, 1986.

16 Pugh L. G. C. E.: Cardiac output in muscular exercise at $5800 \mathrm{~m}$ (19,000 ft). J Appl Physiol 19:441-447, 1964.

17 Racine P., Klenk H. O., Kochsiek K.: Rapid lactate determination with an electrochemical enzymatic sensor. $Z$ Klin Chem Klin Biochem 13: 533-539, 1975.

18 Reeves J. T., Groves B. M., Sutton J. R., Wagner P. D., Cymerman A., Malconian M. K., Rock P. B., Young P. M., Houston C. S.: Operation Everest II: preservation of cardiac function at extreme altitude. J Appl Physiol 63: 531-539, 1987.

19 Saltin B., Grover R. F., Blomqvist C. G., Hartley L. H., Johnson R. L. jr.: Maximal oxygen uptake and cardiac output after 2 weeks at 4,300 m. JAppl Physiol 25: 400-409, 1968.

20 Stenberg J., Ekblom B., Messin R.: Hemodynamic response to work at simulated altitude, 4,000 m. J Appl Physiol 21 : 1589-1594, 1966.

2 Sutton J. R., Reeves J. T., Wagner P. D., Groves B. M., Cymerman A., Malconian M. K., Rock P. B., Young P. M., Walter S. D., Houston C. S.: Operation Everest II: oxygen transport during exercise at extreme simulated altitude. J Appl Physiol 64: 1309-1321, 1988.

22 West J. B., Boyer S. J., Graber D. J., Hackett P. H., Maret K. H., Milledge J. S., Peters R. M. jr., Pizzo C. J., Samaja M., Sarnquist F. H., Schoene R. B., Winslow R. M.: Maximal exercise at extreme altitudes on Mount Everest. JAppl Physiol 55 : 688-698, 1983.

Dr. G. Ferretti

Dept. of Physiology

C. M. U. Rue Michel-Servet 1

CH-1211 Geneve 4

Switzerland 